\title{
O buriti e a rosa: aspectos da linguagem em Grande sertão: veredas
}

\author{
Fabiana Buitor Carelli Marquezini I USP
}

Resumo: Este ensaio procura demonstrar, por meio da análise de certos procedimentos de criação lingüistica e de elaboração estilistica presentes em Grande sertão: veredas, que a linguagem do romance (1) não é única nem unívoca, mas se modifica nos diferentes episódios do livro, plasmando, assim, os significados específicos de cada uma das partes do texto; e (2) vincula-se intimamente a aspectos estruturais dessa narrativa, relacionando-se, por exemplo, a questões de gênero.

Palavras-chave: Literatura Brasileira, Guimarães Rosa, Crítica Literária.

A imensa capacidade de criação lingüística constitui, sem dúvida, a face mais aparente de toda a obra de Guimarães Rosa e, por isso, talvez a mais comentada e analisada. O uso inusitado da matéria expressiva pelo escritor conduz o leitor não apenas por uma recriação da linguagem do sertão mineiro, que sem dúvida existe em suas obras, mas também através do universo, transformado, dos cerca de vinte idiomas que Rosa podia, segundo consta, ao menos ler (Lorenz, 1983: 82).

Essa exacerbada criatividade lingüística, criação voltada para a origem, para a gênese do sentido, parece ter levado à conhecida "dificuldade" 
da obra de Rosa, ao seu quase hermetismo, que aflora em depoimentos de alguns leitores seus, como o crítico uruguaio Emir Rodríguez Monegal:

Logo que o abri [Grande sertão: veredas], descobri porque Guimarães Rosa era (apesar de sua fama no Brasil) um autor ainda desconhecido. Li e reli e tornei a reler as três ou quatro primeiras páginas do romance. Não direi que não entendi nada porque seria exagerar. [...] Porém o que eu havia aprendido [de português], e que me permitia circular sem lágrimas pela literatura brasileira ou portuguesa, parecia nada, frente a essas primeiras formidáveis páginas de Grande sertão: veredas (Monegal, 1983: 52).

No sentido da decifração dessa linguagem "estranha" é que foram sendo publicados, desde a década de 1950, vários estudos sobre os "aspectos formais" do texto rosiano, procurando, de modo às vezes mais, às vezes menos abrangente, sistematizar os tipos de criação vocabular e sintática do escritor mineiro.

Um dos primeiros a tratar do assunto foi M. Cavalcanti Proença, em seu Trilhas no Grande Sertão. O último ensaio dessa obra, intitulado justamente "Aspectos formais", foi publicado originalmente em março de 1957, pouco depois do lançamento do romance. A leitura que Cavalcanti Proença faz da "língua" de Grande sertão: veredas parte da sensação de que o resultado da pesquisa formal de Rosa no livro é "um uso expressivo e às vezes hermético" da linguagem, o que renderia ao trabalho do autor a classificação de "barroco", já que tenderia à ênfase:

[Em Grande sertão: veredas,] o romancista aproveitou alguns dos elementos estilísticos comuns aos autores do período assim denominado [barroco], sem cingir-se totalmente à ortodoxia dos seus postulados estéticos [...]. Esses elementos são, em sua essência, resultante expressional de uma carga emotiva muito forte, cuja primeira conseqüência é o pendor enfático, irrepresável nos limites da linguagem comum" (Proença, s.d.: 70).

Cavalcanti Proença também faz, nesse ensaio, um levantamento de certos procedimentos de criação lingüística que encontra no Grande sertão e uma classificação tentativa dos resultados. Em relação à originalidade vocabular da obra, ele propõe as seguintes categorias: emprego de latinismos, arcaísmos e de formas em desuso; palavras de uso corrente com significação arcaica; emprego de termos eruditos; indianismos (em menor número); criação 
de palavras (por derivação); e atualização de transformações fonéticas. Quanto à inovação sintática, o autor identifica: o uso de recursos reduplicativos expletivos, considerando como tal também o emprego de dois ou mais adjetivos para o mesmo termo; os pleonasmos (assim considerados o emprego de termos cognatos, de vocábulos com identidade de sentido, as repetições, a pluralização "desnecessária" e os superlativos enfáticos); e os desvios na ordem sintática com finalidade de ênfase (Proença, s.d.: 71-7).

O autor enumera ainda alguns procedimentos estilísticos que considera particularmente característicos de Grande sertão, especialmente o que chama de jogos sonoros, como o uso de aliterações, coliterações (repetição alternada de fonemas surdos e sonoros correlatos, como f/v, t/d), criação de rimas em consonância (palma/palmeira, por exemplo), rimas toantes, ritmo e onomatopéias, tudo isso no texto em prosa. Esses recursos são vistos pelo crítico como exemplificações do pendor lúdico desse texto, além de terem a finalidade de chamar a atenção do leitor para o romance pelo uso de uma espécie de "ultra-expressividade" insistente:

Para manter em permanente vigília a atenção de quem lê, todos esses vocábulos de som e forma inusitada funcionam como guizos... (Proença, s.d.: 85$)$.

Finalmente, Cavalcanti Proença procura definir alguns processos de criação vocabular dentro das chamadas derivações, em certos momentos apontando recorrências que poderiam delinear um sentido comum para procedimentos semelhantes. É assim, por exemplo, que ele considera algumas prefixações como intensificadoras de sentido (como em relimpar e trestriste), sem, no entanto, encontrar significação clara para outras (como deerrado e envinha), vistas como não dotadas de "intenção [semântica] precisa" (Proença, s.d.: 82-9).

Percebe-se, assim, que a ênfase constitui, de modo generalizante, a principal hipótese explicativa de Cavalcanti Proença para os procedimentos estilísticos inovadores de Grande sertão: veredas, hipótese esta ligada, para o ensaísta, a outra característica mais ou menos unânime da obra de Rosa, a suposta "oralidade" de sua linguagem:

Dada a busca da oralidade, a linguagem de Guimarães Rosa não pode deixar de ser examinada sob esse aspecto. Convém, no entanto, esclarecer 
que o aproveitamento das peculiaridades orais, no caso, não implica em [sic] reprodução documental da linguagem falada. O que existe é a estilização dos processos expressivos que a caracterizam e de suas tendências para a intensificação.

Charles Bally já anotara que, na linguagem falada, a exageração ou ênfase tem como característica tender sempre para o absoluto e ser permanentemente afetiva em sua maneira expressional (Proença, s.d.: 78).

No contexto do Grande sertão, a interpretação de Cavalcanti Proença parece válida, já que estamos diante de um texto supostamente narrado oralmente por um ex-jagunço, que é Riobaldo, ainda meio submerso, enquanto personagem, no universo pré-literário e pré-alfabetizado das "linguagens do mato" (lembrando que Riobaldo, apesar de sertanejo e jagunço, sabia ler e escrever). O esforço lingüístico de criação seria assim, no romance, e de um ponto de vista bem genérico, um esforço de mímese ou de representação: elaboração de um discurso que simulasse, de modo verossímil, as características da expressão oral desse narrador.

É a generalidade dessa hipótese, no entanto, que parece problemática e, de certo modo, facilitadora. Assumindo-a como correta, tenderíamos a interpretar toda a inovação lingüística do romance como estilização da cultura oral sertaneja e deixaríamos de lado todo o complexo leque de estrangeirismos, entre outros elementos, que também fazem parte de sua composição discursiva e que remetem, não ao sertão, mas a traços formais, mais ou menos claros, provenientes da cultura erudita do autor.

No entanto, a hipótese da representação lingüística do sertão, não somente em Grande sertão: veredas, mas também em outros escritos de Rosa, parece ter sido a que mais vingou. Na mesma linha de análise, Paulo Rónai faz uma leitura do volume de contos Primeiras estórias, de 1962, que destaca, entre outros traços, os procedimentos de criação verbal de Rosa, como os processos de derivação e composição de palavras e inovações sintáticas, enfatizando e detalhando aspectos da sonoridade no texto rosiano e reservando uma parte do ensaio para elencar certas características lingüísticas e discursivas dos contos lidos como expressão de falas populares ou regionais.

1. Expressão de João Adolfo Hansen (2000).

2. A introdução de Rónai (1968) foi incluída em Primeiras estórias a partir da $3^{\text {a }}$ edição (janeiro de 1967). 
Mais do que a análise lúcida de alguns procedimentos formais adotados pelo escritor em Primeiras estórias, porém, o melhor do texto de Rónai consiste justamente nas ressalvas que faz ao método crítico que ele mesmo adotou ali. Depois de proceder a um levantamento consideravelmente detalhado das inovações lingüísticas de Rosa, ele adverte: "os processos estilísticos do autor não devem ser avaliados fora do clima de intencionalidade que lhes cabe no contexto" (Rónai, 1968: lii), ou seja, no interior de cada narrativa, sob pena de, no esforço crítico, se "empalharem" ou mumificarem significados moventes e cambiantes para cada situação. Um pouco antes, a respeito da abordagem que fará na seqüência, o crítico diz:

Nas considerações seguintes, tenta-se não a catalogação dos recursos estilísticos manejados no presente volume (e que daria outro volume), e sim, apenas, a indicação exemplificada das tendências a que correspondem. Não se ignora o risco deste trabalho: os espécimes montados em alfinete com fins de coleção, rígidos e murchos, podem parecer meras esquisitices e até monstruosidades, por mais que vicejem e resplandeçam no contexto de seu ambiente natural, vitalizando-o e animando-o" (Rónai, 1968: XLII)

A advertência pode ser tomada, aqui, como direção a ser seguida: em meu levantamento dos recursos formais e estilísticos de Rosa em Grande sertão: veredas, procurei verificar como a palavra vale no seu contexto, e não fora dele. Assim, se as palavras inventadas e seus processos de composição podem ter significados mais ou menos comuns em diferentes situações discursivas, palavras e processos necessariamente constroem a significação dentro de cada texto, e interpretá-las deste modo, em sua relação com o todo de que fazem parte, e não com um suposto universo exterior a elas, é que deve constituir, em minha opinião, o esforço maior da crítica.

$\mathrm{Na}$ seqüência dessas abordagens, às quais as observações seguintes muito devem, minha leitura pessoal dos aspectos de linguagem em Grande sertão: veredas parte do princípio de que o autor não apenas privilegiou, nesse romance, alguns processos de criação verbal em detrimento de outros, conforme as necessidades expressivas dessa narrativa em particular, como também de que podem ser encontradas diferenças significativas de criação de linguagem entre as partes desse mesmo texto, de acordo com as características estruturais que lhe são próprias e que vão estabelecendo seu sentido mais geral. 
O objetivo desta análise é mostrar que, se é possível identificar, entre os diversos processos de criação de linguagem observados nas obras de Rosa, alguns de sua preferência e próprios de seu estilo pessoal de escrever, os mesmos processos podem, de acordo com a narrativa em que são empregados, ter significados diferentes e atuar de modo a enfatizar seus traços específicos. Com isso, o que se quer é devolver à criação lingüística de Rosa sua especificidade literária, invertendo um pouco a perspectiva crítica: em vez de enxergar o autor, algo abstratamente, como "criador de linguagens" (Santilli, 1998), o que se deseja é entendê-lo como produtor de uma história cujo significado começa e, de um certo modo, termina nela mesma.

Em Grande sertão: veredas, podem ser observados vários dos procedimentos de criação verbal já apontados pela crítica, e ainda outros. Para melhor sistematização, procurei organizá-los, a partir do levantamento de suas ocorrências concretas, em quatro grandes categorias: ${ }^{3}$

- Léxico: todos os procedimentos ligados à elaboração ou uso diferenciado de palavras, como criação ou uso de termos de origem popular ou coloquial; neologismos criados a partir do português, assim consideradas tanto as palavras formadas por processos de derivação (afixação, derivação regressiva) ou de composição; estrangeirismos, como um tipo especial de neologismo, destacado desse grupo para fins de interpretação; arcaísmos ou emprego de palavras em desuso com a significação original ou outra; e palavras empregadas com mudança de classe gramatical (caso de substantivação de palavras, substantivos transformados em adjetivos, adjetivos tornados advérbios ou advérbios tornados adjetivos, etc.).

- Sintaxe: todas as construções sintáticas que, por um motivo ou por outro, modifiquem a estrutura frasal típica do português culto, entre as quais destaco, por razões de interpretação: redundâncias, não apenas de sentido, mas também de função sintática na frase; adjetivação dupla, que, sendo um tipo de redundância sintática, é tão freqüente que merece aqui menção especial; inversões, às vezes até modificando o sentido da sentença; e descristalização de expressões ou frases feitas.

3. Leve-se em consideração que esta, como toda categorização, é relativamente arbitrária e leva em conta os grupos mais adequados à análise que se procurará fazer depois. 
- Recursos de estilo e figuras de linguagem: imagéticos, em geral ligados à natureza do sertão; várias ocorrências de animalização; e recursos que chamei genericamente de poéticos, pela alta densidade de trabalho plástico com a linguagem (em geral, trechos que combinam vários procedimentos estilísticos).

Sendo Grande sertão: veredas o longo "mono-diálogo" que é, fala ininterrupta e caudalosa conduzida desde o - do início até o $\infty$ final, e porque justamente recriação de um diálogo que suprime a voz do interlocutor, o livro não possui capítulos. No entanto, até pela manutenção da verossimilhança entre esse discurso romanesco e a performance oral que ele finge ser, a narrativa é estruturada em episódios. A memória de Riobaldo volteia, sem ordem cronológica, entre fatos vividos e "casos" ouvidos por ele, que são incorporados ao texto muitas vezes com a função retórica da exemplificação ou da prova (Aristóteles, s.d.: 34). Aliás, é possível afirmar, no caso do Grande sertão, que a própria vida de Riobaldo, e não só as historietas que ele, como narrador, (re?)conta, é tratada por ele como uma prova retórica da sua afirmação inicial, um pouco duvidosa (e 'duvidante'), de que o diabo não existe, sendo o livro todo uma grande peça oratória a defender esse argumento:

Então? Que-Diga? Doideira. A fantasiação. E, o respeito de dar a ele assim esses nomes de rebuço, é que é mesmo um querer invocar que ele forme forma, com as presenças!

Não seja. Eu, pessoalmente, quase que já perdi nele a crença; mercês a Deus; é o que ao senhor lhe digo, à puridade (Rosa, 1967: 10).

Além disso, a leitura de Grande sertão: veredas como uma longa peça retórica também explicaria, de certa forma, uma de suas características mais evidentes: a falta de uma cronologia linear (especialmente no início), pois, nesse sentido, o agrupamento entre argumentos e provas (no caso, os episódios da narrativa) seria mais importante, dentro da funcionalidade estrutural do texto, do que o encadeamento seqüencial da ação narrada. A lógica temporal do livro, portanto, seria fundamentalmente retórica, e não apenas narrativa.

Do ponto de vista da linguagem, que é o assunto central deste ensaio, pode-se dizer que os episódios do livro também se distinguem, e que os procedimentos de criação lingüística adotados por Rosa em cada um deles constituem a matéria verbal significante pela qual seus significados mais profundos se constroem. É assim que o levantamento dos tipos de 
procedimentos criativos mais freqüentes nos diversos episódios pode nos levar a uma compreensão mais abrangente, não só de cada 'caso' contado ou de cada momento da ação em si, mas também da função destes, tanto narrativa quanto retórica, no todo do romance.

\section{Noite sem boca, cafarnaum}

A estrutura episódica do Grande sertão é grandiosa e complexa. Grosso modo, pode-se dizer que o romance se divide em seis grandes momentos $^{4}$ e é repartido ao meio pelo episódio do julgamento de Zé Bebelo, como também por um intervalo (aproximadamente quatro páginas) de profundas reflexões do narrador a respeito desse acontecimento e de suas conseqüências sobre a ação desenfreada e, sob o ponto de vista cronológico, mais linear que acontecerá daí em diante.

A divisão do livro em episódios serve para que melhor se compreenda como, nos volteios da trama narrativa de Riobaldo, a língua híbrida usada pelo narrador-jagunço plasma e constrói o sentido de maneira profunda e sempre diferente. Se Riobaldo afirma, a certa altura, que

o mais importante e bonito, do mundo, é isto: que as pessoas não estão sempre iguais, ainda não foram terminadas - mas que elas vão sempre mudando. Afinam ou desafinam (Rosa, 1967: 20),

o mesmo se pode dizer de seu jeito de falar, de criar uma linguagem só sua, que se faz à medida que a sua narrativa é, também, criada, e de acordo com os procedimentos mais apropriados à construção do significado.

4. 1. Da abertura do romance até o aparecimento de Nhorinhá e Ana Duzuza; 2. A partir da história de Nhorinhá, passando pela primeira e frustrada travessia do Liso do Sussuarão, sob as ordens de Medeiro Vaz; 3. A travessia do Rio São Francisco, acompanhado pelo "Menino", seguida da morte da Bigrí, mãe de Riobaldo, do estágio como professor de Zé Bebelo, na Fazenda Nhanva, e da entrada na jagunçagem e do período passado sob as ordens do Hermógenes, terminando com o 'causo' da Maria Mutema; 4. As reflexões na Guararavacã do Guaicuí, o julgamento de Zé Bebelo e a morte de Joca Ramiro; 5. O pacto com o demônio e a chefia de Riobaldo; 5 . O episódio final, da luta entre Diadorim e Hermógenes, no Paredão. 
Para indicar como isso acontece no Grande sertão, analisarei contrastivamente a configuração lingüística de dois episódios dessa narrativa: o período que Reinaldo e Riobaldo passam no acampamento do Hermógenes e a descoberta do amor de Riobaldo por Diadorim, na Guararavacã do Guaicuí.

A estada de Reinaldo-Diadorim e de Riobaldo no acampamento do Hermógenes, sob as ordens do diabólico "jagunço pactário", corresponde a um momento da narrativa imediatamente anterior à prisão de Zé Bebelo e ao famigerado episódio do julgamento. É nesse momento que Riobaldo, ao conviver com aquele que virá a se tornar seu inimigo mortal, passa a melhor conhecê-lo - e a mais odiá-lo:

E mesmo forte era a minha gastura, por via do Hermógenes. Malagourado de ódio: que sempre surge mais cedo e às vezes dá certo, igual palpite de amor. Esse Hermógenes - belzebu. Ele estava caranguejando lá. Nos soturnos. Eu sabia. Nunca, mesmo depois, eu nunca soube tanto disso, como naquele tempo. O Hermógenes, homem que tirava seu prazer do medo dos outros, do sofrimento dos outros. Aí, arre, foi que de verdade eu acreditei que o inferno é mesmo possível (Rosa, 1967: 139).

O inferno era mesmo possível, e era ali. Se o Liso do Sussuarão já fora descrito por Riobaldo, a essa altura do texto, como um lugar ínfero, o acampamento do Hermógenes não ficava por menos: "Ah, lá era um cafarnaum. Moxinife de más gentes, tudo na deslei da jagunçagem bargada. [...] Às primeiras horas, conferi que era o inferno" (Rosa, 1967: 123).

Do ponto de vista da linguagem, é possível perceber que as maneiras de expressar as duas situações, travessia frustrada do Liso do Sussuarão e acampamento do Hermógenes, se assemelham: em ambos os episódios, é grande a ocorrência, no texto, de neologismos, de palavras fora de sua significação comum, de estrangeirismos, arcaísmos e também de um tipo de articulação sintática por vezes rompida ou truncada. No entanto, entre o "raso pior havente" do Liso do Sussuarão e o acampamento, há duas diferenças fundamentais: no Liso do Sussuarão, Riobaldo e o grupo não permanecem, enquanto que, no acampamento, ele e Reinaldo ficam por um bom tempo, a ponto de o narrador comentar, até surpreendentemente, diante

5. Segundo Nilce Sant'Anna Martins (2001), moxinife é forma não dicionarizada que significa "confusão", "mistura", redução do termo moxinifada, registrada pelo Novo Dicionário Aurélio e também por Antônio Geraldo da Cunha. 
do ódio pelo Hermógenes e do incômodo frente aos "maus" hábitos jagunços: "Aí, com três dias, me acostumei" (Rosa, 1967: 123). Além disso, o Liso do Sussuarão era um descampado sem dono, onde quem reinava era a natureza áspera. No inferno do acampamento, porém, havia um chefe, e esse chefe, o Hermógenes, era quase o próprio demo, ou um seu "alferes" (Rosa, 1967: 132): "belzebu", no dizer de Riobaldo.

Isso faz com que, além da multiplicidade espantosa de neologismos, de termos coloquiais e de inovações sintáticas, mostrem-se também abundantes alguns recursos de estilo, como a utilização de imagens metafóricas e também a animalização, que expressam justamente o "belzebu" Hermógenes, seus "asseclas" e seu universo. Os arcaísmos e estrangeirismos também aparecem de modo significativo, assim como os usos diferenciados de palavras em contextos completamente inovadores.

Entre os neologismos, observa-se, no trecho, uma profusão de derivações prefixais por des-, salientando o caráter "contrário" daquele acampamento "dos diabos": desapeamos, deslei, desapartar, desamotinavam, descômodo, desentendi (no sentido de 'não entendi'), a variante disidéia, desrazoadamente, desaprumavam, desinfluindo, desapartava, desprevino, desvalesse, descarecia, dessossego, desinquietação, desbarrigado, descareci, desléguas. Destaque-se que a maior quantidade de termos derivados desse prefixo se encontra no primeiro trecho da estada com os hermógenes, enfatizando a descrição do local e dos costumes do grupo. As derivações regressivas também são numerosas e expressam o traço animalesco e "retrógrado" da situação (acampo, no lugar de 'acampamento', de rempe, no lugar de 'de repente'; os substantivos safano, jóvia, ajunta, cantarol, alcanço, jorna, semelbo, nublo, cafuz, encrespo, lufo, chio, louvo; o verbo conchegamos), assim como as composições, que criam palavras híbridas e estranhas, similares aos homens-animais que habitam o acampamento (sendo o Hermógenes o maior deles) e suas metamorfoseantes ações (fechabrir, quem-com-quem, de contra-lado, rapa-tachos, no abre-boca, abrenunciei, faca-punhal, meio-mil, nãostante, mal-assasse, sobrefiz, pé-pubo, estarestâncias, muito segundas-e-sábados, malagourado, testalto, de sem-tempo, sãossalavá, contrafim, entre outras).

6. Riobaldo refere-se ao Hermógenes como sendo "alferes" de Joca Ramiro. A aplicação para a figura do demônio é minha. 
À semelhança do que ocorre no episódio do Liso do Sussuarão, e aqui talvez ainda mais intensamente, encontram-se nesse trecho estrangeirismos (bedém, do árabe badan, 'capa contra chuva'; guardei, restado, bruta e vero, do italiano guardare, restare, brutta e vero, respectivamente 'ver', 'ficar', 'feia' e 'verdadeiro'; arriba e guapo, do espanhol; esmarte, do inglês smart, 'bem posto', 'esperto'); arcaísmos (coroça, 'capa de palha de buriti'; fiúza, 'satisfação', 'confiança', do latim fiducia; joliz, 'alegre', 'divertido'; felão, 'desleal', 'pérfido', provavelmente do francês félonie, pelo latim carolíngio félon; espórtula, 'esmola', do latim sportula; soez, 'reles'; o freqüente nanja, 'de maneira nenhuma'; de prão, que equivale a 'de chofre')'; e palavras completamente estranhas ao leitor urbano comum, a maioria de extração regional ou popular, como moxinife, 'confusão', 'mistura'; xetas, regionalismo para gesto que imita um beijo; mengando, fazendo movimentos eróticos; castanhetando, estalando com os dedos; tranquibérnia, 'tramóia'; rafaméia, 'ralé', 'escória'; baldrocavam, faziam troca desonesta; redoleira, 'redonda'; tranquia, 'barricada com madeira'; berêu, vocativo para 'homem', 'cara'; dobros, 'bornais'; e assim por diante. Observe-se que os termos trazidos da linguagem popular e sertaneja reforçam o caráter regional do fenômeno social do jaguncismo, descrito detalhadamente por meio do grupo dos hermógenes, representado de maneira crua para o leitor da cidade como algo estranho a ser traduzido, decifrado. A presença mais abundante de arcaísmos, por sua vez, volta a reiterar a visão do grupo jagunço como algo antigo, retrógrado, avesso ao progresso, que constitui um dos fios temáticos do Grande sertão.

Sobre o aspecto lexical, é preciso comentar ainda a considerável quantidade de palavras que, embora dicionarizadas, são utilizadas no trecho com funções e significados bem diferentes dos usuais. São expressões como me superintender, taqueava o meu chofre, aperfeiçoando os dentes, empacotava boa quantia, cismo de fio de cabelo, envenenava do juizo, sacolejavam bestidades, horas safadas, contumaz dormia, de rota abatida, contar corrigido, arisco de aviso, no próximo de meu cochicho, fiquei inteiriço, acheguei meus dentes, não encostava amizade, desertando da cobiça, no rés dele, desertado de minha companhia, esfriar as pontas do corpo, peso anoitecido, amanhecido nos olhos, mordido e remordido sofrimento, entre

7. Segundo informações colhidas em Nilce Sant'Anna Martins (2001), e também no dicionário de Aurélio Buarque de Hollanda Ferreira. 
tantas outras. Além de conferir ao texto um tom coloquial, elas também criam uma sensação de estranhamento que remete àquela experimentada por Riobaldo ao entrar no acampamento dos jagunços e com eles conviver, sem compreender direito os seus costumes, no início, e sem ser também compreendido por eles.

É como se mesmo aquilo já há muito conhecido, colocado naquele contexto estranho, se transformasse em novo. A amizade de Riobaldo com Reinaldo, por exemplo, aparentemente encarada como "normal" pelo grupo de Titão Passos, é objeto de estranhamento e de piadas por parte dos "hermógenes", assim como os traços femininos de Diadorim:

Mas Diadorim sendo tão galante moço, as feições finas caprichadas. Um ou dois, dos homens, não achavam nele jeito de macheza, ainda mais que pensavam que ele era novato. Assim loguinho, começaram, aí, gandaiados. [...] A fumaça dos tições deu para a cara de Diadorim - "Fumacinha é do lado - do delicado..." [...] (Rosa, 1967: 123).

O caráter quieto e observador de Riobaldo também incomodou os outros companheiros no início:

Ao às-tantas me aceitaram; mas meio atalhados. Se o que fossem mesmo de constância assim, por tempero de propensão, ou, então, por me arrediarem, porquanto me achando deles diverso? Somente isto nos princípios. Sendo que eu soube que eu era mesmo de outras extrações (Rosa, 1967: 127).

Além disso, há o estranhamento do próprio Riobaldo em relação ao caráter gratuitamente violento e maldoso dos demais, especialmente do Hermógenes. Sobre o hábito jagunço de afiar os dentes a faca, para se parecer mais feroz, Riobaldo comenta:

[...] eles queriam completo ser jagunços, por alcanço, gala mestra: conforme o que avistei, seguinte [...]: que estavam desbastando os dentes deles mesmos, aperfeiçoando os dentes em pontas! [...] Senhor ver, essa atarefação, o tratear, dava alojo e apresso, dava até aflição em aflito, abobante. [...] Assim um uso correntio, apontar os dentes de diante, a poder de gume de ferramenta, por amor de remedar o aguçoso de dentes de peixe feroz do rio de São Francisco - piranha redoleira, a cabeça-de-burro (Rosa, 1967: 127). 
Sobre o Hermógenes, pondera: "Mas o Hermógenes era fel dormido, flagelo com frieza. / Ele gostava de matar, por seu miúdo regozijo. Nem contava valentias". Ao fim, chega à conclusão de ser, ele mesmo, uma "mistura", naquele "mundo misturado": "Então, eu era diferente de todos ali? Era." E, logo depois: E eu era igual àqueles homens. Era" (Rosa, 1967: 132-3). Igual e diferente, conhecido e estranho, velho e novo, ou novo, a partir do velho, num outro contexto - como a linguagem.

Em relação à sintaxe, chamam a atenção no episódio as inversões e as negações duplas, ressaltando a negatividade, a vilania, o diabolismo do lugar e do grupo. São exemplos de inversões nesse episódio: Se estavam, Se vai lá, Me fez careta, Se esperava, Me senti, Me disse, Me entristeceu, Se engrotou, Me irava, Me fiz, Me lembro, Me deu, Me entende, Me alembrei, entre outros casos de pronome átono no início de sentença; e expressões como tinha nunca botado, de inteira noite, feio pegadio, o igual, sempre sendo, numa certa morte dessas, mesmo estava sem remédio, dessa noite esquecer não posso, combate quanto, de cada forte fogo, empalidecido muito, cachaça de pago imposto. Quanto às negações duplas, encontram-se: ninguém não se meteu, nem o senhor não pense, nem o nome dele não podia, nem eu não imaginava, acho que nem não, nem olhei nunca, nada não disse, nem feito meninos não sendo.

Essas negações reverberantes são mais freqüentes na primeira parte do episódio, que corresponde à descrição do acampamento e do Hermógenes ("o diabo, no meio do redemoinho" de jagunços). A segunda e a terceira partes, por sua vez, em que se narram os combates contra Zé Bebelo e seus soldados, deixam entrever várias questões de concordância (outra tropa de guerra, prontos para virem; tu vem; tu mesmo vai; tu não quer; povo nosso demos [...] fogo, nossa gente [...] estavam escondidos; tu tem; Nós vive; aquilo me corria só os calafrios), que também já aparecem, embora em menor número, no início do episódio (toda conversa é miudinhos tempos; tu é; tu não quer, o povo de São Francisco soube, se reuniram, e deram fogo; tu carrega; era umas doideiras), talvez ressaltando, lingüística e literalmente, a falta de concordância, a dissonância declarada entre Riobaldo e os hermógenes (além de, é claro, numa interpretação mais superficial, remeter às concordâncias típicas da fala popular):

Entremeando, eu comparava Zé Bebelo com aquele homem. Nessa hora, eu gostava de Zé Bebelo, quase como um filho deve de gostar do pai. [...] De repente, eu via que estava desejando que Zé Bebelo vencesse, porque era 
ele quem estava com a razão. Zé Bebelo devia de vir, forte viesse: liquidar mesmo, a rás, com o inferno da jagunçada! [... eu] estava tudo traindo, traidor, no cabo do meu coração (Rosa, 1967: 132).

Observe-se que, aqui, as concordâncias opostas à norma culta acontecem não só no sentido de pluralizar a ação, ou de dar-lhe caráter grupal (outra tropa... prontos, o povo... se reuniram), mas de também de singularizá-la (tu tem, Nós vive, me corria... os calafrios, era umas doideiras), como se houvesse, e havia, uma presença individual dissonante e singularizante no grupo, que era justamente o Tatarana.

Esse universo ao mesmo tempo conhecido e novo ("Digo ao senhor que aquele povo era jagunços; eu queria bondade neles? Desminto. Eu não era criança, nunca bobo fui. Entendi o estado de jagunço, mesmo assim sendo eu marinheiro de primeira viagem" - Rosa, 1967: 131) é destacado, ainda, pela descristalização de expressões ou frases feitas, também freqüente no episódio: o fechabrir de olbos, em vez de "num abrir e fechar de olhos"; leão coração, em vez de "coração de leão"; versa por detrás, no lugar de "vice-versa"; de sem-menos, em vez de "sem mais nem menos"; o dia deu, em vez de "amanheceu"; O que tivesse de ser, somente sendo, em vez de "O que tiver de ser, será"; vara verde, ver, em vez de "feito vara verde", em sertão plano, em vez de "em pleno sertão"; com meu coração nos pés, por pisável, em vez de "com o coração na mão".

O traço primitivo e retrógrado do mundo jagunço ganha destaque ainda nas imagens utilizadas para expressá-lo. Universo de instintos, é como se quase todas as criaturas que dele viessem a fazer parte descessem os degraus da escala evolutiva e se tornassem animais, como animais são Hermógenes e seus subordinados, os originais habitantes.

É esse universo tenebroso, diabólico e obscuro, "noite sem boca", que Riobaldo quer vencer ao decidir, bem mais à frente, fazer o pacto, pensando que só poderia vencer o mal pelo mal e se permitindo transformarse numa espécie de arremedo do Hermógenes, cobra jararacuçu, chefe "UrutuBranco". Uma leitura detida dos descaminhos do grupo pelo vilarejo do Sucruiú, dos momentos que antecedem o pacto nas Veredas-Mortas e, depois, do episódio da chefia de Riobaldo descortina novamente a mesma descida a territórios infernais e como que um retorno a estágios primitivos e inferiores da travessia humana. 


\section{Do inferno ao paraíso}

Depois da guerra infernal contra os soldados de Zé Bebelo, do fatídico julgamento e da partida do comandante vencido para o exílio em Goiás, a narrativa de Riobaldo alcança um remanso:

A Guararavacã do Guaicuí: o senhor tome nota deste nome. [...] Mas foi neste lugar, no tempo dito, que meus destinos foram fechados. Será que tem um ponto certo, dele a gente não podendo mais voltar para trás? Travessia de minha vida. Guararavacã - o senhor veja, o senhor escreva. As grandes coisas, antes de acontecerem (Rosa, 1967: 220).

Foi na Guararavacã, lugar que, segundo o narrador, deixou de existir, que Riobaldo tomou consciência da natureza de seus sentimentos em relação a Diadorim:

O nome de Diadorim, que eu tinha falado, permaneceu em mim. Me abracei com ele. Mel se sente é todo lambente - "Diadorim, meu amor..." Como era que eu podia dizer aquilo? (Rosa, 1967: 221).

Nesse momento breve, em que o traço épico da guerra cede lugar ao lirismo da paixão, a narrativa se distende, o ritmo cai, e "rompe", "arrebenta" o rio represado de imagens poéticas e sonoridades, repletas de doçura e ligadas à natureza, adormecidas até então no estrepitar do combate, como dormidas haviam permanecido as emoções:

O que sei, tinha sido o que foi: no durar daqueles antes meses, de estropelias e guerras, no meio de tantos jagunços, e quase sem espairecimento nenhum, o sentir tinha estado sempre em mim, mas amortecido, rebuçado. Eu tinha gostado em dormência de Diadorim, sem mais perceber, no fofo dum costume. Mas, agora, manava em hora, o claro que rompia, rebentava (Rosa, 1967: 221).

É assim que, durante o episódio, a linguagem acompanha o movimento do texto, instaurando padrões diferentes. Do ponto de vista do léxico, os neologismos, apesar de numerosos nas sete páginas (dois meses, no tempo da narrativa) que cobrem a estada na Guararavacã, quase "empatam", em número, com as chamadas derivações impróprias ou conversões, seguidos 
de perto pelo emprego de termos coloquiais ou de extração popular e pelo uso de palavras em contextos inusitados. Os estrangeirismos, por sua vez, são poucos (somente dois); arcaísmo, apenas um.

Ao se analisarem os neologismos, percebe-se que eles, pelo menos neste fugaz momento do texto, não causam impressão de grande estranheza ao leitor. Pelo contrário, são usados para formá-los, em geral, radicais e afixos bastante comuns na língua; a "mistura" entre eles é que pode ser considerada inusitada.

Entre as derivações prefixais, aparecem formas como desrazoada, referver, desvalendo, desmisturado, desqueriam. À exceção da forma referver, na qual o prefixo re- adiciona ao verbo ferver a idéia de repetição, de intensidade, todas as demais prefixações são feitas, neste trecho, pelo acréscimo do afixo des-. Enquanto em desrazoada, desvalendo e desqueriam, esse prefixo ainda está ligado ao universo jagunço e, portanto, à idéia de "mundo à revelia" que o caracteriza, segundo o narrador, e às noções de avesso, contrário, oposto e negativo, a forma desmisturado abre a possibilidade de uma outra interpretação para o emprego do afixo no contexto, ligada à figura de Diadorim. Essa palavra aparece logo após o balbucio do nome do amigo por Riobaldo, já citado, e à sensação de abraçar-se imaginariamente com ele:

Como é que eu podia dizer aquilo? Explico ao senhor: como se drede fosse para eu não ter vergonha maior, o pensamento dele que em mim escorreu figurava diferente, um Diadorim assim meio singular, por fantasma, apartado completo do viver comum, desmisturado de todos, de todas as outras pessoas - como quando a chuva entre-onde-os-campos. Um Diadorim só para mim. Tudo tem seus mistérios. Eu não sabia. Mas, com minha mente, eu abraçava com meu corpo aquele Diadorim - que não era de verdade. Não era? (Rosa, 1967: 221, grifo meu).

Sabe-se que a sensação da mistura, das coisas fora de lugar, do "desgoverno do mundo" não era muito agradável a Riobaldo, que em geral identificava situações "misturadas" ao violento mundo jagunço e à sua (des)ordem. Imediatamente antes de contar o caso da Maria Mutema, portanto em meio aos sentimentos negativos que o acampamento do Hermógenes lhe recordava, o narrador explicita a seu ouvinte o quanto essa sensação da "mistura" o incomodava: 
Que isso foi o que sempre me invocou, o senhor sabe: eu careço que o bom seja bom e o rúim ruím, que dum lado esteja o preto e do outro o branco, que o feio fique bem apartado do bonito e a alegria longe da tristeza! Quero os todos pastos demarcados... Como é que posso com este mundo? [...] Ao que, este mundo é muito misturado... (Rosa, 1967: 169).

Os termos desmistura, desmisturado, desmisturar aparecem ao longo de todo o romance e em geral indicam o restabelecimento de uma ordem, talvez paradisíaca e anterior à vida, talvez utópica, ou talvez conseguida após o agonizar do jaguncismo, com o velho Riobaldo a levar a vida "de range-rede". De qualquer forma, a "ordem" é sempre vista pelo narrador como melhor do que a "desordem", a mistura diabólica que corre a rua, no meio do redemoinho de acontecimentos. Observe-se, por exemplo, o seguinte comentário de Riobaldo, também a respeito de sua "amizade" com Diadorim, em que desmisturar aparece dotado de um sentido positivo de experiência adquirida, de melhor entendimento: "Pensar mal é fácil, porque esta vida é embrejada. A gente vive, eu acho, é mesmo para se desiludir e desmisturar" (Rosa, 1967: 114).

Em oposição a isso, são várias as ocasiões em que misturar, mistura, misturado são identificados com situações ou aspectos negativos. O Hermógenes, por exemplo, encarnação do mal, é descrito como feito de "um grosso misturado" (Rosa, 1967: 159, grifo meu). Ao prenderem um soldado, durante a luta contra os bebelos, Riobaldo imagina que o Hermógenes irá matá-lo e fica à beira de um riacho, longe da cena, observando a água, "esperando ver vir misturado o sangue vermelho dele" (Rosa, 1967: 184, grifo meu). E, após a notícia da morte de Joca Ramiro, toma conta das palavras de Diadorim uma "misturação de carinho e raiva" (Rosa, 1967: 227, grifo meu).

Nesse contexto, o prefixo des- parece adquirir uma conotação diferente, em que nega o negativo e, assim, instaura o positivo, o belo, o bom, ainda que pouco conhecidos, surpreendentes ou amedrontadores. De fato, a beleza e a "ordem" do sentimento por Diadorim, apesar de intuída

8. Lembre-se, nesse sentido, o comentário de Guimarães Rosa a respeito de sua linguagem a Günter Lorenz: "Não sou um revolucionário da língua. [...] eu preferia que me chamassem de reacionário da língua, lá onde a palavra ainda está nas entranhas da alma, para poder lhe dar luz segundo a minha imagem" (Lorenz. 1983: 84). Esse traço idealizante também faz parte da obra rosiana. 
através da natureza delicada e exuberante da Guararavacã, está encoberta pela noção do desvio, do amor proibido entre dois homens:

"Se é o que é" - eu pensei - "eu estou meio perdido..." Acertei minha idéia:
eu não podia, por lei de rei, admitir o extrato daquilo. Ia, por paz de honra
e tenência, sacar esquecimento daquilo de mim. Se não, pudesse não, ah,
mas então eu devia de quebrar o morro: acabar comigo! - com uma bala no
lado de minha cabeça, eu num átimo punha barra em tudo (Rosa, 1967: 222).

O pequeno exemplo do prefixo des- deixa entrever a dialética cerrada que compõe o texto de Rosa, em que o bom se transforma em seu contrário e em que o mal se descobre em bem, até que, por fim, se apresente uma terceira e nova ordem, sem Hermógenes e sem Diadorim, sem jagunços e sem sertão. Neste sentido, Diadorim é o exato contrário do Hermógenes, a des-mistura:

Só se pode viver perto de outro, e conhecer outra pessoa, sem perigo de ódio, se a gente tem amor. Qualquer amor já é um pouquinho de saúde, um descanso na loucura. Deus é que me sabe. O Reinaldo era Diadorim - mas Diadorim era um sentimento meu (Rosa, 1967: 236).

Entre as derivações sufixais, mais abundantes que as prefixais no trecho, encontram-se formas como atrasamento, varjaria, vigiação, quebreira, repartimento, pindaibal, formosuramente, renovame e sapal, que chamam a atenção por apresentarem radicais e sufixos relativamente correntes na língua (atras-ar, vigi-ar, repart-ir, sap-o; -mento; -ação, -al, etc.) que se combinam em resultados surpreendentes e originais (de novo, a mistura), talvez para expressar, de modo enfático, a curiosa e amedrontadora fusão homem-mulher em Diadorim. Além disso, percebe-se a tendência à formação de substantivos a partir de verbos, o que remete a um universo originado nas ações humanas, no qual as próprias atitudes de Diadorim, que, na verdade, constituíam seu ser encoberto, se bem observadas pelo inseparável Tatarana, talvez tivessem sido decodificadas de outro modo.

Também chamam a atenção no episódio certas composições bastante originais, por combinação ou justaposição, as quais parecem remeter também ao caráter compósito, masculino e feminino, do jagunço Reinaldo. Entre outros, são exemplos desse tipo de neologismo os termos de tapa- 
cara, tem-te que verde, entre-onde-os-campos, quando mais-olha, sobrestive, sufruía e sem-gracez. Em relação às derivações regressivas, elas são raras, em comparação ao que já se analisou nos trechos anteriores (alguns exemplos são os substantivos endireito, verdejo e remôo). Uma interpretação possível para esse fato é a de que, nesse lugar de natureza exuberante e de sentimentos convulsos e manifestos, tudo acontece pelo excesso, pelo acréscimo, pela adição. Sendo também uma situação predominantemente positiva, em oposição ao mal explícito do acampamento do Hermógenes, essa positividade talvez se expresse pelas idéias de adição e completude, e não pelas de ausência ou falta.

Reforçando ainda a expressão da natureza mutante de Diadorim, há no trecho vários casos de derivação imprópria (emprego de termos com mudança de classe gramatical) e também de uso de palavras em contextos semânticos novos. Esses dois processos são bastante típicos do episódio da Guararavacã em relação ao restante da obra, pois é nesse momento que se questionam, de forma explícita, a sexualidade de Riobaldo e de Reinaldo e, portanto, suas categorizações em termos de homem-mulher, suas "classes", seus "gêneros", por assim dizer. Como nas expressões sem dizer o que a quem, a vão, no sozinho do vago, de derradeiro, balançar esfiapado, do dentro do mato, o bom adormecer, do viver comum, no durar, o sentir, sempres vezes, o secar, o exato, substantivos e adjetivos tornam-se advérbios, advérbios tornam-se adjetivos, e adjetivos, advérbios e verbos tornam-se substantivos, assim também a categorização amorosa e sexual de Riobaldo e Reinaldo mostra-se modificada e complexa para a consciência do narrador-personagem naquele momento de sua história. Trata-se de um universo que pode ser visto como platônico e platonizante, no qual, para o narrador, as aparências despistam e encobrem formas essenciais e mais verdadeiras, apenas vislumbradas ou intuídas, na imaginação ou em sonho:

Um dia, sem dizer o que a quem, montei a cavalo e saí, a vão, escapado. [...] Eu tinha culpa de tudo, na minha vida, e não sabia como não ter. Apertou em mim aquela tristeza, da pior de todas, que é a sem razão de motivo; que, quando notei que estava com dor-de-cabeça, e achei que por certo a tristeza vinha era daquilo, isso até me serviu de bom consolo. [...] Então, deitei, baixei o chapéu de tapa-cara. Eu vinha tão afogado. Dormi, deitado num pelego. Quando a gente dorme, vira de tudo: vira pedras, vira flor. (Rosa, 1967: 219) 
Para essa sabedoria vaga, oculta, também apontavam os pensamentos de Riobaldo durante os primeiros dias na Guararavacã: "Imaginei esses sonhos. Me lembrei do não-saber" (Rosa, 1967: 218). Tudo aparentemente fora de seu lugar, e fora de lugar também as palavras e seus sentidos. Para exprimir a Guararavacã e suas surpresas, era preciso deslocar significados, descobrindo o novo: rompimento de soldados, desenrolar dos bandos, aos gritos de vozear, macias terras, campo solteiro, fizemos grande redondeza, sutil trovão. Tudo sempre o mesmo, tudo diferente: "Naqueles olhos e tanto de Diadorim, o verde mudava sempre, como a água de todos os rios em seus lugares ensombrados" (Rosa, 1967: 219).

Acompanhando a desestruturação das crenças do narrador sobre a realidade e, principalmente, quanto à sua própria identidade, a sintaxe apresenta inversões (seriam Reinaldo e Riobaldo "invertidos", ou "delicados", no dizer de Fancho-Bode?), como Se tinha, Me lembrei, Me a mim (também redundância), Me deu, Me olbou, Me abracei; estruturas redundantes, enfatizando o caráter excessivo, abundante do lugar e dos sentimentos ali acontecidos, como sendo para ser, the a ele podermos valer, nome que chamava-se, me vendo o meu dormir; raras negações duplas, ausência que reforça a positividade da Guararavacã em oposição ao acampamento jagunço (se melhor não seja a gente tivesse de sair nunca, nem coisas assim não acontecem); e alguns truncamentos, referência expressiva ao espanto de Riobaldo diante da súbita descoberta do seu amor por um "igual", de efeito algo tartamudo: feito quisesse, como quando a chuva entre-onde-os-campos, do jeito que decerto cobra pensa: quando mais-olba para um passarinho pegar, p'ra tu leva de presente, quando o céu empoeirado, chega passava.

Mas o mais bonito e característico da "linguagem da Guararavacã" está no seu aspecto estilístico. Nascido da natureza (ainda que escondida sob o gibão de couro de Diadorim) e, por isso, intimamente ligado a ela em muitas de suas formas, o amor na Guararavacã se expressa em imagens de delicadeza rara. São vários momentos, entre eles o revôo dos pássaros à chegada do bando, inclusive do manuelzinho-da-croa, pássaro de Diadorim, e "as garças, elas em asas", diante do "rio desmazelado"; os rebanhos a amanhecerem vagarosos, "suspendendo corpo sem rumor nenhum, no meio-escuro, como um açúcar se derretendo no campo"; o aparecimento / aparição de Diadorim, a vigiar Riobaldo enquanto este dormia e, ao acordar, "ouro e prata que Diadorim aparecia ali, a uns dois passos de mim"; os olhos de Diadorim, 
"como a água de todos os rios em seus lugares ensombrados", olhos de "velhice"; o vento frio, "vento [...] verde", "com todas as almas"; as "saudades, dessas que respondem ao vento"; e o silêncio que se "põe no colo".

Nesse meio, os animais ganham um espaço até então dominado pelos humanos e, diga-se, eles parecem bem mais "humanos" do que os jagunços do Hermógenes:

Lá na Guararavacã, eu estava bem. O gado ainda pastava, meu vizinho, cheiro de boi sempre alegria faz. Os quem-quem, aos casais, corriam, catavam, permeio às reses, no liso do campo claro. Mas, nas árvores, picapau bate e grita. E escutei o barulho, vindo do dentro do mato, de um macuco - sempre solerte. Era mês de macuco ainda passear solitário macho e fêmea desemparelhados, cada um por si. E o macuco vinha andando, sarandando, macucando: aquilo ele ciscava no chão, feito galinha de casa. Eu ri - "Vigia este, Diadorim!" - eu disse; pensei que Diadorim estivesse em voz de alcance. Ele não estava (Rosa, 1967: 220-1).

Além disso, a própria animalização que o narrador faz de si mesmo, ao descrever seus pensamentos sobre Diadorim, ganha nesse contexto outros contornos: "Eu devia de ter principiado a pensar nele [Diadorim] do jeito que cobra pensa: quando mais-olha para um passarinho pegar. Mas - de dentro de mim: uma serepente" (Rosa, 1967: 221). Ao contrário do que acontecia no acampamento jagunço, e acontecerá, mais à frente, quando RiobaldoTatarana vier a se tornar o chefe Urutu-Branco, a serpente, aqui, não possui vinculação com o mal, mas explicita a conotação também sexual dos sentimentos de Riobaldo em relação a Diadorim, sempre expressa de maneira sutil. Esse aspecto fica ainda mais claro na seqüência: "[...] uma serepente. Aquilo me transformava, me fazia crescer dum modo, que doía e prazia. Aquela hora, eu pudesse morrer, não me importava" (Ibid.).

Por sua vez, a figura do macuco, quase personificado, a rolar os olhos em volta como a procurar alguma coisa, com a invocação do nome afetivo de Diadorim, e a freqüente comparação deste a pássaros nos mais diversos momentos da narrativa, estendem para a relação Riobaldo-Reinaldo a afirmação feita por aquele em relação à ave que andara por ali "sarandando", "macucando":

9. Sobre a sutileza da expressão erótica do amor no romance de Guimarães Rosa, v. Marília Librandi Rocha (1997). 
"Era mês de macuco ainda passear solitário - macho e fêmea desemparelhados, cada um por si" (Rosa, 1967: 221). O mesmo acontecia, naquele momento, entre Riobaldo e Diadorim: macho e fêmea, também desemparelhados. O comentário do narrador lembra e, de certa forma, parodia o Gênesis bíblico:

E criou Deus o homem à sua imagem: à imagem de Deus o criou: machoe fêmea os criou.

E Deus os abençoou, e Deus lhes disse: frutificai e multiplicai-vos, e enchei a terra, e sujeitai-a: e dominai sobre os peixes do mar, e sobre as aves dos céus, e sobre todo o animal que se move sobre a terra (Bíblia sagrada, s.d.: 2).

A relação com o texto bíblico reforça o caráter edênico e positivo da Guararavacã do Guaicuí frente às paragens infernais do acampamento chefiado pelo "cão" Hermógenes. Nesse local, animais e homens conviviam ainda em relativa harmonia, anterior a todo o mal, e homem e mulher quase acabam por se descobrir nus diante dos próprios sentimentos, não fosse a súbita chegada da notícia tonitruante da morte do chefe-maior Joca Ramiro pelas mãos do próprio Hermógenes, a qual provoca a "queda" vertiginosa dos personagens até o duelo final na rua do Paredão. Na Guararavacã, Riobaldo come do fruto de sua árvore pessoal do conhecimento, muito embora tenha depois se esforçado por sufocar e esquecer o que, intuitivamente, aprendera. E a imagem da "serepente" interior também se reveste, nessa versão do paraíso, de perfeita coerência, "ser" que tenta e que provoca a descoberta do amor.

Por fim, há no trecho uma personificação que percorre todo o texto e que se explicita também no episódio, reiterando a preponderância de uma ordem natural, talvez divina, sobre o desejo e as ações livres do homem, preso às leis do destino e a uma verdade maior, muitas vezes oculta ou mal compreendida: "Sertão é isto: o senhor empurra para trás, mas de repente ele volta a rodear o senhor dos lados. Sertão é quando menos se espera; digo" (Rosa, 1967: 218).

\section{O buriti e a rosa: natureza e criação}

As leituras feitas acima a respeito dos aspectos léxico, sintático e estilístico de episódios específicos do Grande sertão: veredas desmistificam 
algumas crenças e opiniões a respeito do romance. A primeira delas é a de que a obra seja constituída de um tipo de linguagem relativamente uniforme, ainda que inovadora, e que se possa resumir em algumas fórmulas simplificadoras, como "língua do sertão", "linguagem oral", ou, por outro lado, "estilo moderno" ou "criação revolucionária", à semelhança do que comumente se diz a respeito da obra literária de Rosa.

Embora seja realmente possível apontar certos procedimentos criadores como constantes, tanto no livro quanto na obra de Guimarães Rosa em geral, os quais constituiriam o idioleto, ou o estilo, do autor, verificase que, mesmo no interior de uma única obra, no caso o Grande sertão: veredas, os efeitos de linguagem adotados variam, em qualidade e também em quantidade, de acordo com as funções que assumem nos diferentes contextos/episódios da narrativa. De acordo com essa visão, a linguagem possui, no romance, função estrutural, e qualquer generalização a respeito dela para o livro como um todo, sem considerar sua estrutura episódica, parece, no mínimo, temerária.

Há, no entanto, algumas tendências. Nos episódios analisados, verificaram-se certos padrões de linguagem que talvez possam ser definidos como, "a língua do diabo" e a "língua do amor" (em contraste com uma suposta "língua sobre o diabo", que aparece nos trechos mais filosóficos do livro e que não foram analisados aqui). Esses diferentes "idiomas", tal como explicitados, correspondem aos veios épico-romanesco e lírico do romance e vão mudando e se repetindo, grosso modo, à medida que um ou outro aspecto emerge e se sobressai nesse rio caudaloso que é a narrativa do exjagunço Riobaldo. Como uma voz, que se adoça, endurece ou vagueia dependendo do assunto no qual se detém, a linguagem de Riobaldo também é plástica, e se plasma de acordo com as necessidades estruturais e temáticas do texto, do qual constitui o aspecto mais aparente.

Resumindo, talvez possamos afirmar que, no Grande sertão: veredas, a "língua do diabo", tal como analisada no episódio do acampamento do Hermógenes, é marcada, no léxico, pelas noções de novidade e estranhamento (a partir dos muitos neologismos) e pelo traço arcaizante, pela sintaxe truncada e tartamuda e, do ponto de vista do estilo, pelas animalizações; e a "língua do amor", explicitada no episódio da Guararavacã do Guaicuí, tem como traços predominantes a mutabilidade, a reversibilidade e a mistura, no léxico e, principalmente, quanto ao estilo, a riqueza e delicadeza das imagens ligadas à ordem paradisíaca da natureza. 
A análise lingüística empreendida também desmistifica, de certo modo, a opinião comum de que a chamada "língua de Guimarães Rosa", pelo menos no âmbito do Grande sertão: veredas, seria a mera recriação de uma suposta "língua do sertão" ou de um tipo de registro ou norma lingüística oral dominante no norte de Minas Gerais e arredores. Como se viu, traços de oralidade e regionalismos existem nas diferentes linguagens que compõem o livro. Além disso, não há como negar o trabalho documental de Guimarães Rosa, que transparece não somente na incorporação de termos regionais ao texto, mas também na de processos morfológicos e sintáticos típicos da fala popular. Curiosamente, no entanto, oralidade e regionalismos parecem submergir diante da profusão de processos criadores léxicos e sintáticos claramente originados na cultura altamente erudita e letrada de Rosa, que incluía seu profundo conhecimento do português, inclusive arcaico, e de diversas outras línguas e literaturas. No âmbito do romance, mesmo expressões e estruturas de clara "aparência" coloquial ou popular vão acabar exercendo, num nível mais profundo de significação, funções diversas, como por exemplo o uso de pronomes pessoais oblíquos no início de sentenças, típico do português falado no Brasil mas que, no texto, e ligado a outros procedimentos, vincula-se muito mais à criação de um efeito de inversão e negatividade do que à tentativa de mimetização de um traço da oralidade - apesar de, é claro, não deixar de fazê-lo.

Ao fim e ao cabo, o que se percebe é que regionalismo e oralidade atuam, em Grande sertão: veredas, como uma espécie de fundamento e de disfarce para outras linguagens e outros registros - sendo o disfarce, o encoberto, o oculto alguns dos aspectos temáticos e estruturais mais marcantes do livro. Nesse sentido, a obra de Rosa está mais próxima da "máquina retórica de trituração de retóricas” que João Adolfo Hansen enxergou nela: a fala ininterrupta e totalitária de Riobaldo devora, incorpora e deglute discursos, histórias, línguas, registros, memórias, documentos para constituir o seu sentido, o seu texto, a sua fala (Hansen, 2000: 50).

Essa visão do texto de Rosa desautoriza, assim, a sua leitura como um mero retrato ou reconstrução do universo sertanejo, explicitando o caráter pessoanamente "fingidor" do romancista, que joga com os cânones, línguas, registros e, fazendo-o, de alguma forma os incorpora e, mais que isso, os subverte. O alegado regionalismo ou a "recuperação" da oralidade supostamente empreendidos por Guimarães Rosa no Grande sertão: veredas mostram-se, dessa forma, justamente por serem discurso e literatura, não como marcas da 
"realidade", mas como traços da ficção . No fundo, o que se "recupera", nesse texto, parece pouco, e tudo se cria, porque o resultado do esforço de linguagem que se elabora no discurso é um objeto de natureza literária. Nesse universo, a utopia (até antropológica) da "recuperação" e da preservação do sertão "perdido", do arcaico, do popular e, sob um dado ponto de vista, de um certo aspecto da nacionalidade permanece para sempre busca, um eterno ou-topos, o não-lugar. Como criador privilegiado, Guimarães Rosa sabia disso, e nos propôs o sertão enquanto paradoxo.

Abstract: Through the analysis of certain procedures of linguistic creation and stylistic elaboration in Grande sertão: veredas, this essay aims to demonstrate that the language, in this novel, (1) changes in the different episodes of the book, thus building up the specific meanings of the several parts of the text; and (2) is closely related to some of the structural aspects of this narrative, as the genre.

Key words: Brazilian Literature, Guimarães Rosa, Literary Criticism

\section{Referências Bibliográficas}

ARISTÓTELES. Arte retórica e arte poética. Trad. de Antônio Pinto de Carvalho. Rio de Janeiro: Ediouro, s.d.

BÍBLIA SAGRADA. Trad. de João Ferreira d'Almeida. New York: American Bible Society, s.d. HANSEN, João Adolfo. OO: a ficção da literatura em Grande sertão: veredas. São Paulo: Hedra, 2000.

LORENZ, Günter. "Diálogo com Guimarães Rosa”. In COUTINHO, Eduardo F. Guimarães Rosa. Rio de Janeiro/Brasília, INL, 1983 (Col. Fortuna Crítica, 6). p. 62-97.

MARTINS, Nilce Sant'Anna. O léxico de Guimarães Rosa. São Paulo: Edusp, 2001.

MONEGAL, Emir Rodríguez. "Em busca de Guimarães Rosa". In COUTINHO, Eduardo F. Guimarães Rosa. Rio de Janeiro/Brasília, INL, 1983 (Col. Fortuna Crítica, 6). p. 47-61.

PROENÇA, M. Cavalcanti. Trilhas no Grande sertão. [Rio de Janeiro?]: MEC, s.d.

ROCHA, Marília Librandi. As espantosas palavras: uma análise de Grande sertão: veredas. Dissertação de mestrado. São Paulo: FFLCH/USP, 1997.

RÓNAI, Paulo. "Os vastos espaços”. In ROSA, João Guimarães. Primeiras estórias. 4.ed. Rio de Janeiro: José Olympio, 1968. p. xxiv-lviii.

ROSA, João Guimarães. Grande sertão: veredas. 5.ed. Rio de Janeiro: José Olympio, 1967.

SANTILLI, Maria Aparecida. "João Guimarães Rosa e José Luandino Vieira, criadores de linguagens". In Scripta, Belo Horizonte, v.2, n.3, p. 221-233. 